\title{
Lived citizenship as the locus of political agency in participatory policy
}

\author{
Kirsi Pauliina Kallio, Jouni Häkli and Pia Bäcklund
}

Space and Political Agency Research Group (SPARG)

University of Tampere

Centre of Excellence in Research on the

Relational and Territorial Politics of Bordering, Identities and Transnationalization (RELATE)

Academy of Finland

Abstract: Participatory policies seeking to foster active citizenship continue to be dominated by a territorial imagination. Yet the world where people identify and perform as citizens is spatially multifarious. This article engages with the tension between territorially grounded perceptions and relational modes of practicing political agency. Studying empirically the Finnish child and youth policies we address jointly the participatory obligations that municipalities strive to fulfill, and the spatial attachments that children and young people establish in their lived worlds. To this end we introduce the concept of lived citizenship as an interface where the territorially-bound public administration and the plurality of spatial attachments characteristic to transnational living may meet. We conclude by proposing a regrounding of lived citizenship in both topological and topographical terms as an improvement in theoretical understanding of mundane political agency and as a step towards more proficient participatory policies. 
Keywords: Lived citizenship; topology; topography; participation; political agency; public administration; child and youth policy

\section{Lived citizenship as the locus of political agency in participatory policy}

\section{Introduction}

This article is premised on two broad multidisciplinary discussions that have caught much attention during the past two decades. Both address the partial break up of territorial bounds, one from the vantage point of changing public administration and the other from the perspective of transforming patterns of identification and belonging among citizens. In Western democracies, public administration is characterized by a move from territorial government towards more complex networked multi-level and multi-actor forms of governance (e.g. Hajer 2003; Sam and Sherer 2006; Beveridge 2012; Faludi 2012), which has been considered a threat to the transparency of public administration and challenge to its democratic basis (e.g. Skelcher and Torfing 2010; Torfing et al. 2009; Mäntysalo and Saglie 2010). Concurrently, people’s identities have been understood as tied to multi-layered and dynamic processes of lived citizenship rather than to static administrative territories (e.g. Mitchell 2003; Desforges et al. 2005; Staeheli 2011; Tambakaki 2011). This is seen to disconnect people from their living environments, and national societies as a whole (e.g. Coulson 2004; Nownes 2011). Even if differently oriented and contradictory in some aspects, these discussions share the belief that to a lesser or greater extent, a broad-ranging development of de-territorialization is at play in the contemporary world.

These two distinct developments and discussions come together in the contemporary trend in Western democracies, whereby citizen participation has become an established concept in the public administration rhetoric (Innes and Booher 2004; Leal 2007 Cornwall 
2008; Bäcklund and Mäntysalo 2010; Silver et al. 2010; Delwaux and Schoenaers 2012; Leino 2012; Bäcklund, Kallio and Häkli 2014). Despite the increasingly complex territorial settings in both public administration practices and citizen's lived realities, local governments in Finland and elsewhere are fostering civic participation through their legally determined territorial frameworks. Hence, community-anchored initiatives and other place-based participatory strategies and projects flourish, prompting people to activate as members of certain regional units that are defined according to their place of residence, study and workplace, parish, school district, or other categorical spatial association (cf. Leino and Laine 2012; Wood 2012). Even the web-based forums organized by public administration often take this locus of participation for granted (e.g. Feldmann-Wojtachnia et al. 2010; Kim 2012), producing what Ash Amin $(2004,41)$ critiques as 'tyranny of belonging to a "local community” with shared interests', and Mark Purcell $(2006,1923)$ describes as 'the local trap [which] entices us to prioritise the interests of the local residents over wider publics'.

The latest turn in this development is the acknowledgement of hitherto neglected groups of people, such as children and young people, as important receivers of participatory services and actors in their local communities (e.g. Tisdall et al. 2006; Tracy and Turfy 2007; Millei and Imre 2009; Lazar 2010; Percy-Smith 2010; Kallio \& Häkli 2011a). The expansion of participatory policies to ever more aspects of social life has gradually built interesting tensions into local government: Officially it is obligated to building participatory systems on the basis of territorial jurisdiction, but to actually succeed in engaging people it should be able to recognize the dynamism and multifariousness of lived citizenship beyond any fixed areal frameworks.

In this article we wish to shed light on this tension that we frame as a mismatch between territorially grounded perceptions informing the participatory policies that seek to foster active citizenship, and forms of political agency situated in the relational world that 
ultimately is not neatly territorially organized. Our premise is that even if challenged by deterritorializing forces, the nation-state - divided into variably mandated counties and municipalities, and allied with each other to form supra-national regions - is a fundamentally territorial system (Jones and MacLeod 2004; Desforges et al. 2005; Murphy 2012). All shifts and amendments to its modus operandi must therefore recognize this premise, if aiming at a conceivable change. Taking seriously this predicament, the article proposes that the acknowledgement of practices of lived citizenship as significant political agency is a step towards developing more proficient participatory policies and practices.

Our rethinking of citizenship along a topographical-topological axis builds on the work by Engin Isin (2009, 2012), Lynn Staeheli (2011; Staeheli et al. 2013), Katharyne Mitchell (2003, 2006, Mitchell and Parker 2008), and others who have engaged with the spatial complexities of lived citizenship in the transnationalizing world (e.g. Desforges et al. 2005; Wood 2012, 2013; Lister 2007; Kallio and Häkli 2011a). The argumentation links with present debates on territorial-relational space in human geography, with reference to related theorization in neighboring disciplines (e.g. Massey 1992; Mol and Law 1994; Murdoch 1997; Jones and MacLeod 2004; Giaccaria and Minca 2011; Mezzadra and Neilson 2012; Murphy 2012; Secor 2013; Häkli 2013). In terms of political theory we follow the path paved by Hannah Arendt $(1958,2005)$, seeking to advance the phenomenological understanding of political agency in line with Clive Barnett (2012), Mustafa Dikeç (2013) and Kirsten Simonsen (2013), and practice-grounded conceptions of democracy, spatial belonging, participation and urban planning (e.g. Hillier 2003; Ortner 2006; Healey 2010).

The article proceeds as follows. First we present the studies to which we base our approach, accompanied by a short introduction to the Finnish administrative system and child and youth policy that we target empirically. These are followed by three sections that make explicit the discrepancy between the spatial attachments established by children and young 
people in their lived worlds, and the spatial imagination informing administrative strategies and practices that aim at supporting youthful participation. The analysis seeks to understand jointly the obligations the municipalities strive to fulfill and the daily lives that children and young people lead, so as to form grounds for an approach that acknowledges territoriality as political-administrative reality and spatial relationality as lived actuality. The concept of lived citizenship, as embedded in a spatial frame that challenges the juxtaposition between topographical and topological perspectives, is then introduced as an interface where the territorially-bound public administration and the plurality of spatial attachments characteristic to transnational living may meet.

\section{Exploring participation in Finnish child and youth policy and public administration}

This article draws upon our longstanding research on public administration and child and youth policy. We have explored administrative developments related to urban planning and participation from various institutional and civic perspectives, and policy rhetoric, strategies and the related legislative processes in municipal, national and international contexts (e.g. Häkli 1998, 2009; Bäcklund and Mäntysalo 2010; Faehnle, Bäcklund and Tyrväinen 2011; Kallio and Häkli 2011a; Kallio 2012; Kanninen, Bäcklund and Mäntysalo 2013; Häkli and Kallio 2014a). In addition to these, we have recently carried out an ethnographic study locating children and young people’s experiences and views concerning participation, belonging and communality (Kallio 2014a, 2014b, 2015). The empirical analysis presented in the next three sections is part of the project Preventing Children's Marginalization through Place-Based Participation that brings together these two research strands (see also Bäcklund, Kallio and Häkli 2014).

The Finnish administrative system relies on municipal self-government, which is strong but nevertheless heavily conditioned by national legislation and policy making that sets 
various formal and practical requirements, including the promotion of civic participation. Consequently all Finnish municipalities have created their own participation policies and plans of action. The latest turn in this 'participation hype' is the growing involvement of minor citizens. Since 2009, municipalities have been legally obliged to consider the hearing, participation and empowerment of children and young people on strategic and operational levels, related to personal (e.g. child welfare, health care), institutional (e.g. schools, kindergartens), local (e.g. zoning, traffic planning), domestic (e.g. national environmental policy) and supra-national (e.g. children’s rights principles) concerns. ${ }^{1}$

Following the spirit of the United Nations Convention on the Rights of the Child (1989, see also UN 2009), the current legislative climate in Finland implies that, regardless of the fact that they are not legally responsible for themselves or eligible to all forms of political citizenship, children and youth should be considered full members of their communities (Kallio and Häkli 2011a; cf. Tisdall et al. 2006; Millei and Imre 2009; Larkins 2013). In the name of equality, their voices should not be evaluated nor their opportunities to express opinions limited on the basis of age. Yet, as people entitled to specific protection from manipulation and exploitation, underage people cannot be engaged with the ideological political system and their comments may not be assessed as grounded in party politics. The 'child’s voice' is, hence, construed as non-ideological and above mundane political debates. This tangle of youthful participation, leaning on the image of 'innocent children' free from (adult) political concerns and stakes (cf. Valentine 1996), sets fair challenges to local administration (Bäcklund et al. 2014). When translating national requirements to municipal strategies, plans of action and practical arrangements, the local administrative personnel are compelled to consider youthful participation simultaneously as a right of the child, an administrative issue and lived reality. 
Our latest study traces these interpretations of youthful citizenship in the six biggest cities in Finland (Helsinki, Espoo, Tampere, Vantaa, Turku, and Oulu) and contrasts them with children and young people's own portrayals of their lived words. The following analysis is based on a data set collected in 2009-2013, including (1) key policy documents related to youthful participation and service provision, (2) expert interviews and thematic essays by civil servants involved in child and youth participation, and (3) children and young people’s biographical place-based narratives (comprised from child and youth produced maps, dialectic interviews, thematic stories and art work). The joint analysis of these data seeks to advance understanding about the spatial attachments of youthful citizenship in the contemporary transnational world, and particularly the disconnection between official conceptions and experienced realities.

\section{Youthful experiences of spatial belonging}

Our research traced youthful experiences of spatial belonging with a focused ethnographic study in two middle-class neighborhoods, involving fifth graders (11-12 years of age, $n=74)$ and ninth graders (15-16 years of age, $n=55$ ) from three different schools. The field work was carried out in Tampere and Helsinki, two cities that have followed rather distinct paths in their participation strategies (see next section). The participants were given six mapping platforms ${ }^{2}$ and asked to denote where their life takes place and what places, regions, and routes are important to them. They were instructed to use color codes to specify their markings in line with traffic light categories: green for positive things, red for negative things, and yellow for neutral things. After this, the participants were individually interviewed to shed light on their spatial relations, and later they could complement these narratives by essays and drawings.

The forms of spatial attachment expressed by our youthful participants varied notably, with no clear linkage to collective factors such as age, gender, or school class. Some 
described their lived world chiefly as networks where places near and far get meanings and connect by the significant people, things, and events associated with them. Others' experiences of spatial belonging were strongly region-based but not necessarily mainly with reference to their residential area and the school, as is typically assumed in public administration. Similarly to networks, these attachments build up through subjective experiences, meaning that their scalar extents and locations of belonging do not follow a generic line. Also spatial configurations that could be described as chameleonic appeared. These shifting assemblages tying together 'matters of importance' changed shape and content very swiftly and were therefore better identified in linguistic than cartographic depictions. All three forms of spatial attachment could lead to differently scaled worlds composed in and through the lived youthful realities that we strove to understand.

Our first finding was that the young participants clearly favored different mapping platforms (also Kallio 2014b). Whereas some produced a detailed neighborhood map with numerous marks describing their everyday routines, others skipped this template almost entirely and presented their bundle of important issues on the national scale, for instance. The local and regional platforms were variously employed as well, sometimes portraying a dense grid of relatives, friends, commercial centers, hobbies, and recreation areas, or just one or two markings signposting the school and the home. Also the large scale maps were diversely crafted and engaged with different themes, which we found particularly revealing of the plurality of children's concerns.

Some of our participants used the global and the continental platforms to represent the mediated world where they live. Their maps depict national contexts of their favorite television series, films, and games; natural environments that had struck them in documentary or animated films; cultural origins of cool things such as cartoons, toys and media technology; and inviting tastes, smells and materials familiar from commercials and popular cultural 
media. These maps are revealing of landscapes of the mind, i.e. mindscapes that reflect experiences of spatial belonging (Kuusisto-Arponen 2011, 191, also Dahlgren 2006). In contrast, other participants presented learned descriptions about the world of war, poverty, livelihood, and religious and cultural differences, merging attitudes and information delivered by the school, the media, and their family (also Kallio 2015). These maps provide a window to the outcomes of institutional spatial socialization, another process by which people learn to locate themselves and others in the world (Paasi 1999; Slavtcheva-Petkova and Mihelj 2012; Silova et al. 2014). Yet still other children spotted the large-scale maps with places they had visited, where their relatives and friends had been to or lived, and places they hoped to visit often making no difference between Finnish and 'foreign' locations. These maps hint at transnational lived citizenship that confuses the national/cosmopolitan division, which Lynn Staeheli (2011, 397) presumes ‘a better approximation of political life in the global north than is widely accepted' (cf. Mitchell and Parker 2008).

The scalar plurality of spatial attachments became apparent also when we asked the children to explain their choice of color codes. For instance, Russia was often colored red 'because Finland has been subjugated by it'. At some point, we caught ourselves implicitly associating all red markings concerning Russia this way until we learned that two girls specified their notes quite differently. For them, Russia was familiar from everyday encounters (personal accident during a vacation in Russia and a rather strict gymnastics teacher of Russian origin). It is these kinds of encounters that Sarah Elwood and Katharyne Mitchell $(2012,11)$ deem important for children and young people’s ‘positioning as social subjects and [as] a site where they can shape this positioning'. Hence, seemingly obvious spatial configurations, such as 'Russia', may well remain scalarly open-ended realities to children and youth. 
Furthermore, the participants did not take the provided scalar platforms for granted as separate entities. As we went through their markings in a dialectic manner, we often ended up moving back and forth between the maps as they were built translocally (cf. Saldanha 2002; Desforges et al. 2005). For instance, a girl who marked her aunts' home in one of the smallerscale maps could draw straight parallels with this place and odd locations in Spain (shared vacation), Paris (the aunt's previous home) and Eastern Finland (family owned summer house). Having portrayed one of her important contexts of living, she then connected this network with other strands that crisscrossed her mapping platforms. Another example of such relational use of scale came from two circles of friends who were selectively enacting the mediated transnational world in the creation of an 'us'. This involved bringing together elements from various scalarly divergent sources (e.g. TV series, family practices, school peer communities, hobbies, travels, role playing games, popular music scene, cartoons, and sports events), and embedding these in everyday practice by transforming them to serve their own ends. The created ‘we are us' embraced and looked like a chameleonic spatial assemblage taking different shapes in space and time. 'Hot topics’ and 'looks' could alter even between our field work periods. Yet this did not endanger the socially recognized existence of the group in the school community, which reveals its established nature.

Finally, the existence of scalar dimensions could be entirely overlooked. In several cases one of the maps was filled with detailed markings and others were used just to emphasize these spatial associations. For example, some of our participants colored the state territory green on all large-scale maps. When asked about this, they told that it indicates their locale of living and not the nation-state. In the smaller-scale maps they marked this particular location green, be it the city, the neighborhood or a place in the countryside, and presented all of their experiences and views as invested there. These cases serve as good examples of region-based spatial belonging that may settle variably, both in terms of place and scale. 
These observations, concerning different forms and scalar dimensions of spatial belonging, should be read as examples scratching the surface of the lived worlds of our child and youth participants, yet hopefully indicative of the breadth of their experienced spatial attachments. In targeting middle-class neighborhoods we wanted to approach 'normal'3 children and youth from roughly similar social backgrounds rather than groups that are particularly disadvantaged or affluent. Using this sample as a ‘critical case’ (Flyvbjerg 2001, 79), we wish to suggest that the plurality of youthful spatial attachments is a prevailing condition rather than dependent on categorical differences or residential diversity. Our findings are thus indicative of what Amin (2004, 37-38) calls 'a heterotopic sense of place [...] trans-territorial by its very definition [generating] associations and discursive engagements at a variety of spatial scales and a variety of spatial forms'. With diversified experiences of spatial belonging and issues at stake, children and young people’s interests and engagements are variably located, inconsistent and spatio-temporally shifting.

\section{Administrative ideas and interventions in supporting youthful participation}

This section is based on the analysis of policy documents through which the six largest Finnish cities delineate children and young people's participation. The policies are motivated most importantly by the Youth Act (2006), the Child Welfare Act (2007), and the national Child and Youth Policy Programme (2007-2011). ${ }^{4}$ Whereas the Youth Act stresses participation as a civic right of the child (public life) in line with the European Union White Paper on Youth (Eur-LEX 2001), the Child Welfare Act is more concerned with the civil rights of the child (private life), thus meeting the primary requirements of the $\S 3$ and $\S 12$ in the UN Convention on the Rights of the Child (1989). This said, since both laws keep faithfully with the spirit of international child's rights (see UN 2009), the legislation contains some overlap, which is visible also in the subsequent municipal policy documents. 
Some general features for organizing youthful participation can be identified in our target cities. Four key arenas of participation are noticed by all: The school, the communal youth center, the Internet, and the public services directed at children, youth, and families. This four-fold strategy is implemented in a somewhat different way in each municipality. From our perspective, the geographical imagination that informs the implementation of these policies interestingly reveals the cities’ assumptions concerning youthful citizenship’s spatial attachments.

The school (including the day care system) is identified as the most obvious context of youthful participation as it involves practically all children and youth, and has effective means for implementing their rights comprehensively and equally. ${ }^{5}$ Yet also the limitations of school-based participation are broadly acknowledged. Citizenship education and participatory interventions can be included in regular school work only to some extent, and the democratic structures such as school councils and student parliaments involve a certain number of interested pupils but remain typically distant to the majority (see also Kallio 2014a). Therefore, the communal youth centers (sometimes involving comparable clubs and activities targeted at younger children) have been found a complementary structure involving the youth during their free time. As youth centers function with the same spatial logic as the schools (i.e. on the basis of residential areas), together they form an inclusive participatory system based on regional units.

Children and young people's active agency in the information society is also systematically noticed within municipal administration. What is typically referred to as 'the net' is portrayed as a space where they spend plenty of time from early age, and thus it seems to offer yet another wide-ranging arena for participation. ${ }^{6}$ By hearing and involving children and young people through this 'pervasive space' is the third component of a comprehensive strategy that is to provide all youthful inhabitants the opportunity to 'participate in matters 
concerning them', as required by the legislation. And fourth, following strictly the letter of the Child Welfare Act, all cities assert that children and young people’s opinions and views are taken into account in services and planning processes identified as pertinent to them individually and as part of their families, reference groups and compeers. These 'youthful concerns’ are typically identified through local public services provided in residential districts (e.g. recreational facilities, parks and transportation).

While in many aspects participatory policies are similarly organized in our target municipalities, there are differences too. One major difference pertains to the very basics of democracy (Bäcklund et al. 2014). Some municipalities have invested heavily in representative structures whereby participation is managed and facilitated by appointed teachers, youth workers, and administrative personnel. All cities have some kind of a representative system but the Oulu and Tampere models take the idea furthest, adapting to the ‘international standard’ (cf. Matthews and Limb 2003; Tisdall et al. 2006; Tracy and Turfy 2007). Geographically, their models follow the traditional idea of nested hierarchy beginning from the individual pupil and her school class, and moving scale by scale all the way to the municipal government (and potentially beyond). As children begin the school, by default they enter a democratic system offering them civic roles as voters and potential candidates. School classes elect representatives to school councils, schools and youth centers to local forums, and these forums to municipal children's and youth parliaments, where they manage common matters in their positions of trust. Direct democracy is enabled through web-based platforms and youth centers where individuals can have a say in matters bothering them, and these concerns are considered by the municipal body when applicable. Ideally, in this type of a system information and ideas move back and forth between individual pupils, student groups, school classes, school councils, local forums and municipal parliaments, and pupils take 
concrete measures to influence matters important to them individually and collectively at all levels of the system.

These models lean strongly on the school as a national institution that arranges children and youth on the basis of 'district', 'school', and 'class' for 9 years at the least. This organization follows a particular logic where chronological age, residential area and individual abilities are the most defining attributes. That is, the units are not organized on political grounds and the pupils are not able to choose their reference groups on the basis of their orientation. By replacing inhabitancy with 'studentship' in youthful participation these models turn a pedagogical arrangement into a representative political system, but without providing its participants the opportunity to choose their 'party'. They thus come to imply that youthful citizenship is first and foremost about fulfilling participatory procedures, and that children and young people are not individuals with fundamentally different orientations, attitudes and views of life but instead devoted members of the ‘children's party' (for a national comparison, see Kallio \& Häkli 2011a).

Another territorially grounded but somewhat less institutional participation system has been developed in Espoo and Vantaa where youth centers act as vital sites of participation. In Espoo the neighborhood is identified as the pertinent scale of belonging to children and young people, the adult population, as well as the national and international migrants, with regional equality and the prevention of marginalization in everyday environments as their leading principles in organizing participation. The city is currently augmenting its communal youth center system so that every child and youth would have access to these facilities in their living area, because 'the youth tend not to move more than one kilometer to get services' (City of Espoo 2010, p. 21). Following a slightly different logic, the Vantaa strategy stresses the particularity of these facilities: 'Every youth center will have their own model for participation practice. The youth workers will be provided tailor-made training, noticing their 
skills and assignments.' (City of Vantaa 2010, p.4). This approach is in line with the more general tone of the Vantaa child welfare plan that is strongly supportive of early intervention methods. Whereas Espoo visions youth centers as places where the local children and youth may pop in on their way to the friend's house, the corner store, while walking the dog, etc., Vantaa presumes that the children and youth who utilize these facilities differ from district to district, requiring particular services that fit their needs. Yet common to them is the belief that the communal youth center is the place where the youth can be extensively involved, on a neighborhood basis.

In Helsinki, opportunities for participation have traditionally been organized by different administrative sectors, in various ways and forms. A similar dispersed system has been employed in Turku that is currently constructing its first comprehensive general participation strategy, including child and youth issues. Approaching participation from less formal starting points than the other cities, the Helsinki Youth Department has actively refrained from establishing a conventional municipal youth council. As explicit countermotions, their previous 'Hesan Nuorten Ääni’ (Helsinki Youth Voice) and the latest 'Ruuti' (Gunpowder) are attempts to make space for youth-initiated activities that can be accessed from different parts of the city and do not require long-term commitment.

Yet, despite its alternative approach, the Helsinki participatory system has not resulted in wide-ranging participation. The turnout percentage in open elections for the Ruuti caucus has remained low regardless of the attempts to make it very easy for the youth to vote (the latest voter turnout $6.7 \%$ ). The group responsible for decision making is therefore very selective consisting mainly of those active youth whose friends are also active enough to vote. Furthermore, the ostensibly open 'action groups' are organized at community youth centers, named according to residential districts, and oriented mostly toward local activities. Finally, despite its alternative ideology, the Ruuti initiative too is strongly reliant on school councils 
that are used to disseminate information and hear the 'child's voice' representatively in various issues. Hence, from the point of view of spatial attachments, the Helsinki system does not differ as much from the other five cities as it first seems.

To sum up, the principles according to which our target cities seek to support youthful citizenship range from representative to direct forms of participation, and from categorical to self-organizing participation systems. Nevertheless, the assumptions concerning the spatial attachments of youthful citizenship are strongly territorial in all cities we studied. Echoing at the back of policy documents is a spatial imagination presuming that the environments where children and youth are institutionally placed (the school), where their home resides (youth centers), and where locally embedded matters are discussed (virtual platforms), capture the focal points, reference groups and issues of interest pertinent to their developing and unfolding political agency.

\section{Between administrative and youthful realities}

The previous two sections have sought to illuminate the spatial attachments of youthful citizenship in the lived worlds of children and youth, and as imagined, or perhaps anticipated and hoped for, in municipal strategies and policy documents. This section briefly portrays how people working with child and youth participation issues, and drafting these documents, see the role of their target groups. Their views are contrasted with some findings from our ethnographic study.

The analyzed interviews and essays by 19 civil servants working with child and youth participation issues in the six cities contain implicit and explicit notions of different spatial attachments of youthful dwelling. The gap between the everyday issues and environments of youthful living, and the extensive legislative requirements to organize youthful hearing and 
participation, can be detected from most expert notions. Their responses ${ }^{7}$ to 'What is youthful participation about?' typically begin with views such as these:

'Children and youth need to be offered clear opportunities to participate and influence in everyday matters, in their own lived worlds, at the grassroots level.' (C3/E1)

'Children should be able to participate specifically in matters they have opinions about. I don't think that any field can be demarcated outside participation.' (C6/E1)

'Participation should definitely be enhanced in matters that form children and young people’s life and “the everyday” (C5/E1)

Hence, the general idea of youthful citizenship is broad enough - it is agency defined by places and matters important to the youthful agents themselves. However, as the same experts talk about the spatial settings where youthful participation is supported, and the matters it may concern, we find themes familiar from the policy documents:

'Day care centers and schools have a special status in supporting willingness to participation.' (C5/E2)

'Participation activities may be organized also in other places, though the school is the most important one. For instance day care centers, playgrounds, youth centers, associations, etc.' (C2/E6)

'School councils, youth centers, Tampere youth web-pages and youth representatives in two committees at the local government are the most important channels.' (C4/E4)

'Matters are school lunch, school rules, communality, bullying, school trips, curriculums, use of school facilities... just everything, in collaboration with adults.' (C5/E1)

Certainly, all these are everyday environments and matters that concern children and youth, but they form a rather selected collection of places and matters that are likely to be more important to some people than others, allowing for certain kinds of opinions and forms of agency. They appeal to those children and youth who are interested in the institutionally arranged forms of ‘civic involvement’ (cf. Bragg 2007). This was clearly evident in our ethnographic study where formal participation venues were rarely brought up.

Even though the schools we worked in are actively 'pro-participation' with established strategies and structures, well-motivated staff, and apparently well-functioning student unions 
involving basically all pupils in the system, only two ninth-grade girls in Helsinki (and none in Tampere) mentioned the school participation system. Both girls were members of the school council, one a common delegate and the other acting as the chair. Their narratives portray the council's activities in rather dissimilar ways. The chair conveyed that the council works successfully as a representative system sensitive to individual initiatives and supportive of collective action, nested tightly in the school's administrative structure and connected with the municipal Ruuti forum. In contrast to this, the common delegate stressed the council's detachment from the school community, the council members’ agency and personal gain, and the vagueness of relationships between the council, the rector-led school and the municipal system. Yet the girls agreed on one matter: The issues dealt with by the council concern the school and the participatory system in Helsinki, and the organized activities are oriented respectively.

The low esteem afforded to the school participation system was accompanied by little regard to other organized sites and activities. The second flagship venue of participation, the youth center, was only mentioned by one group of four ninth-grade girls. They had taken part in a participatory youth exchange project, involving fund raising and a trip to Slovakia. The experience had been rewarding and they wanted to continue the dialogue. Yet as they tried to organize a reciprocal visit, their initiative was soon declined as 'too expensive and too complicated' by the youth center administration. Frustration led them to give up going to the youth center but they have kept up the relationships with the Slovenian youth via social media.

Of further interest is that the virtual sites that both Tampere and Helsinki introduce as important channels for straight democracy and participation did not come up at all in the ethnographic study, even if the daily use of virtual space was one of the dominating themes in the interviews. Equally, opinion-statement regarding public services was not mentioned. In 
contrast to this seeming disregard of participation, our young participants expressed broadly that it was comfortable and commonplace to bring up all kinds of troubling matters in the everyday school life, where teachers were open to both individual and collective inquiries and responded as they could. Similarly, nearly all of them went to a hobby where they could participate meaningfully in matters concerning them, as recognized members of their mundane communities. Giving feedback on routinely used private services, such as restaurants and stores, was also mentioned. Finally, opinion statement, expression of concerns, mutual negotiation and other interactive engagements took place in different kinds of virtual settings that were found substantially and/or socially significant.

Hence, the participation fora specifically organized for children and youth hardly came up at all in our ethnographic study, and the participation venues meaningful to them seem to be located elsewhere. This finding indicates that the places and matters mentioned in the excerpts from the civil servant essays are held important by the local government much more than the children and youth whom they seek to involve. The expert interviews largely concur ${ }^{8}$ as they confirm that these systems involve only selected individuals and issues rather than youthful communities at large. In reflecting on the matter, the civil servant responsible for putting together a comprehensive interaction plan in Helsinki states that:

'The student council keeps itself occupied and usually the other pupils don't even know what is done there. And the same goes with other representative structures.' (C2/E4)

Her view is affirmed by another civil servant with long-time experience in municipal citizen participation:

'Youth are drawn to the meeting table or hearing events by the local government, to convey their worries. Those youth who have the best skills and endeavour end up there, but broadbased participation is missing. [...] The artificial child and youth hearing events are agonizing, be they national forums or parliaments. If they are based on democratic school 
communities they are to the purpose. Otherwise I see them as quasi-democratic cheating of young people.' (C5/E1)

Broadening the scope of participation to directions highlighted by our youthful participants, the experts (and the policy documents) do mention some environments that reach beyond institutions and formal participatory structures. In this regard the home and the hobbies are held to be much more important spaces. Yet they are unable to specify how participation might be publically supported in these privately organized settings. Also social media sites and the street are occasionally brought up as places where youth workers interact with the youth. However, the goal is not to support youthful agency in these environments as the projects are centered on traditional youth work (e.g. providing information about public services, discussing with the youth about their problems in family life, getting them off the streets).

In all, the somewhat contradictory messages conveyed by the statements of our expert informants reveal that in public administration there is sensitivity and willingness to identify youthful citizenship in broad terms, but the legislative requirements that direct participatory activities usually lead into categorical solutions that seek to fulfill the letter of the law. Especially those who have worked with child and youth participation issues for a long time are well aware of the incompatibility of children and young people’s variably located lived worlds and the rigid administrative structures. Many of them agonize about knowing what would work for the kids, yet acknowledging the limitations of public administration in advancing along those lines.

\section{Topographically-topologically grounded citizenship as locus of political agency}

Our empirical findings indicate that the spatial attachments by which youthful agents find themselves as belonging are variable and unpredictable, whereas governmental strategies 
predominantly identify them as territorially delimited and locally bound. Consequently, the everyday environments that are meaningful to children and young people differ greatly from those where their participatory agencies are institutionally supported. This discrepancy where youthful citizenship is simultaneously 'unauthorized yet recognized' and 'authorized yet unrecognized', to borrow Saskia Sassen’s (2002, 282-285) conceptualization of 'informal citizenship’, is variably acknowledged by civil servants working with child and youth participation issues. Those who have become attentive to it find themselves in doubt as they are compelled to fulfill the legislative requirements and the prevailing participation ideals without the necessary means to overcome their deficits.

While realizing that a general solution for solving this problematic once and for all is unattainable, we wish to propose an alternative perspective for rethinking the spatial attachments of citizenship. In agreement with Doreen Massey’s (1992, 67) seminal conclusion that 'the conceptualization of space is of more than technical interest; it is one of the axes along which we experience and conceptualize the world', we turn to attempts to theorize space in territorial and relational terms. Instead of valuing one over the other, we accept that both institutional and informal realities continue to be influential as settings for lived citizenship. By bringing together the topographical realities that bind territorially organized administration and the topological realities characteristic to social relationality, we wish to develop an inclusive notion of lived citizenship as the locus of political agency.

In social sciences, the concepts of topography and topology are variably theorized. We lean on a geographical conception of these spatial ontologies, where topography refers to Euclidean spatial relations defined by proximity, distance, location and boundedness. The world thus appears as a continuous space of locations, regions and territories that can be represented cartographically. Topology, instead, designates spatial relationality, the shifting ties of belonging and discontinuity as defined by social relations (e.g. Murdoch 1997; Häkli 
2008; Giaccaria and Minca 2011; Secor 2013). In their editorial to the 2005 special issue in Citizenship Studies, Desforges, Jones and Wood $(2005,445)$ propose that geographers are particularly opportune to engage with different forms of topological citizenship. Yet little work has ensued, and the now-extensive discussion on topological-topographical space is not engaged in the reconceptualization of citizenship per se (but see Lorimer 2010; Mezzadra and Neilson 2012).

The present literature often juxtaposes topographical and topological approaches as alternative ways of conceiving the world in spatial terms. In an exclusively topological perspective, the generally definable and fixed relations between places, things and people cease to appear as meaningful, making way for the transformable spatial attachments qualified by experiences and practices (e.g. Amin 2004; Marston et al. 2005; Thrift 2006). While sympathetic with this thought, we prefer a more inclusive interpretation of spatial relations where both topographical and topological relations can be taken into account, appreciated as simultaneous spatial realities that condition the life of societies, institutions and people (Häkli 2013, Häkli and Kallio 2014b). We find this understanding relevant when discussing contemporary societies that are largely topographically organized but topologically practiced and lived.

By engaging with the concept of lived citizenship within this spatial theoretical frame, we wish to outline a particular way of understanding political agency. Following Hannah Arendt's $(1958,2005)$ conception of political life as vita activa, we propose that political agency ought to be considered a fundamental human capacity that makes possible our living together, providing individuals and collectives means for coping with relational differences (gender, class, race, age, etc.) and relational equalities (subjective uniqueness) that constitute democratic societies as plural: 'Plurality is the condition of human action because we are all the same, that is, human, in such a way that nobody is ever the same as anyone else who 
lived, lives, or will live.' (Arendt 1958, 8). Clive Barnett (2012, 679) identifies this approach as a phenomenological understanding of politics: "The idea that "the political” refers to the problematic of coexistence and association, and that the space of this sharing is constituted by active agents [...] is concerned with the phenomenologies of politics in so far as it focuses in on the processes and activities by which shared worlds of association and co-existence are constituted.' (cf. Isin 2012; Dikeç 2013; Simonsen 2013). In this experience-driven political world, children and youth appear as citizens similar to adults, with different kinds of understandings and perhaps less knowledge about the society than its more experienced members, yet equally challenged by its social plurality (Kallio and Häkli 2011b, 2013; Häkli and Kallio 2014b, cf. Noble 2009; Bartos 2012).

The phenomenological conception of politics fits well together with recent discussions on lived citizenship where mundane practices, acts, experiences and personal understandings are emphasized, rather than legal status or formal practice (e.g. Desforges et al. 2005; Lister 2007; Staeheli 2011; Isin 2012; Larkins 2013; Wood 2013). This literature has set out to question the nation-state as a given scalar entity of citizenship. In Mitchell’s (2003, 389) terms, 'the being and becoming of a citizen as an active participant in a democratic society' are shifting: 'citizenship inexorably moves between scales in different historical and geographical moments, from a local to a national, supranational and transnational set of positionings and back again'. Where citizenship is grounded is hence thoroughly challenged by the multi-scalarity of the lived world.

In this spirit we suggest that while acknowledging the various topological ways of experiencing, belonging and acting, the topographically embedded conception of citizenship is not to be discarded. We do not think the state can simply be replaced by the 'global', 'transnational', or 'topological' world. Rather, we understand citizenry in an Arendtian sense as a form of political agency that enables people to 'work with and get along with others, 
especially those who are perceived as different' in order to take part in the formation of territorial polities, and to perform as transnational players who are 'able to work with, but also around the deterritorialized, highly flexible nature of individual states' constructions of citizenship’ (Mitchell 2003, 389).

We thus approach lived citizenship 'as both a status and a set of relationships by which membership is constructed through physical and metaphorical boundaries and in the sites and practices that give it meaning' (Staeheli 2011, 394). At times, this agency leads to what Isin calls 'acts of citizenship' that produce the citizens themselves and their others as they unfold, but are simultaneously influential in the given society because 'to make a difference is to act; to act is to make a difference' (Isin 2009, 380, see also Isin 2012). In this approach, children and youth, like adults, are acknowledged as distinctive members of their communities in the present and in the future, with particular lifestyles and orientations (Kallio and Häkli 2013). The issues important to them may be variable, and can and need not be known beforehand by the actors and institutions that seek to empower them (cf. Gerodimos 2008; Brough and Shresthova 2012).

Revisiting some of our ethnographic observations may help in elucidating these theoretical ideas (see also Larkins 2013). As a simplifying comparison, let us set the narratives that portray the world as a network spreading to different cultural regions, political societies and natural environments, against those where only the neighborhood map is needed to address the myriad of important matters. It might be tempting to view the former as a form of genuinely topological politics and the latter as indicating a thwarted agency confined by topographical contextuality. Such reading, however, would seriously undermine the idea of lived citizenship as always both topologically and topographically constituted.

It is clear that the children and youth who presented these alternatively framed narratives are differently situated in their lived worlds. Their relations with issues such as 
ethnicity and race, gender and sexuality, affluence and neediness, environmental issues, or any major feature of their societies, are formed through spatial attachments that inevitably constitute their political subjectivities and understandings about the world as a political context (Häkli and Kallio 2014b). Therefore also the matters that concern them - in which they like to be heard, about which they have self-governing opinions, and for or against which they may want to act - vary. To some of our youthful participants the questions of life and death related to the animals they cared for; others agonized about narrow-minded communities that leave little space for difference and alternative life choices; some worried about polluted waters that could be saved only through international collaboration that currently seems unfeasible.

Bringing these findings together with those from our policy analysis suggests that a ‘children’s party' - the idea of a few children representing the many - offers little common ground to youthful participation. While territorially based institutional systems may provide rewarding arenas to some youth or result in affective activities in some cases, as a counter effect they may also come to value differently situated people hierarchically and subordinate some lived worlds while upgrading others. In this view there seems to be little reason to support youthful citizenship separately from the adult world. Children and youth could instead be invited and actively supported to engage with 'pluralistic groups of people who consider particular issues personally important based on self-interest, collective identity, and values’ (Kim 2012, 148, see also Kallio \& Häkli 2015). In bringing together individuals and collectives from different age groups, residential areas, religious communities, national locations, political parties, cultural communities, ethnic groups, and so on, the composition, breadth and spatial ties of such 'issue publics' are unpredictable and shifting as they are held together by the participating people's commitment. Yet this does not mean that their activities could not mobilize in particular scalar dimensions (e.g. locally, regionally, and nationally) or 
involve only certain groups of people (e.g. pupils from one school, youth living in a particular district). Issue-based politics may hence be simultaneously topologically established and topographically mobilized, presenting a flexible form of lived citizenship in which territorial and relational worlds enmesh.

So what might this mean in practice when placed in the context of participatory policies? Our target cities are all currently building virtual forums for youthful participation to be entered privately (at home, hobbies, social media) as well as through organized activities (schools, youth centers, virtual platforms). These online forums are developed in connection with offline participation systems that make possible the regional mobilization of youthful agency in various scalar dimensions. There are also a couple of virtual systems that already operate nation-wide, through which pluralistic youth groups who share similar interests, identities and values could come together in tandem with general participation venues. ${ }^{9} \mathrm{We}$ suggest that connecting children, young people and adults in this vein would extend both the variety and the breadth of participation, offering people opportunities for virtual communal engagement as well as actual participation regardless of their locale, orientation, interests and age. While advancing more inclusive forms of civic engagement sets fair challenges for participatory policies, we consider the goal of bringing together territorial and relational realities of lived citizenship well worth the effort.

\section{Acknowledgements}

We are grateful to the editors and the two anonymous referees for their engaged and helpful comments and suggestions. We also wish to thank the Academy of Finland for financially supporting this work (grants SA258341, SA 134949, SA 253845), and the Space and Political Agency Research Group (SPARG) at the University of Tampere for an inspiring research environment. Special thanks to Elina Stenvall for participating in the ethnographic field work. 


\section{References}

Amin, A. 2004. "Regions unbound: towards a new politics of place.” Geografiska Annaler: Series B, Human Geography 86(1): 33-44. doi:10.1111/j.0435-3684.2004.00152.x

Arendt, H. 1958. The Human Condition. Chicago: University of Chicago Press.

Arendt, H. 2005. The Promise of Politics. Edited and with an introduction by Jerome Krohn. New York: Schocken Books.

Bäcklund, P., K.P. Kallio and J. Häkli. 2014. "Residents, customers or citizens? Tracing the idea of youthful participation in the context of administrative reforms in Finnish public administration.” Planning Theory and Practice 15(3): 311-327. doi:10.1080/14649357.2014.929726

Bäcklund, P. and R. Mäntysalo. 2010. “Agonism and institutional ambiguity: Ideas on democracy and the role of participation in the development of planning theory and practice - the case of Finland.” Planning Theory 9(4): 333-350. doi:10.1177/1473095210373684

Barnett, C. 2012. "Situating the geographies of injustice in democratic theory.” Geoforum 43(4): 677-686. doi:10.1016/j.geoforum.2011.03.002

Bartos, A. 2012. "Children caring for their worlds: the politics of care and childhood.” Political Geography 31(3): 157-166. doi:10.1016/j.polgeo.2011.12.003

Beveridge, R. 2012. “Consultants, depoliticization and arena-shifting in the policy process.” Policy Sciences 45(1): 47-68. doi: http://dx.doi.org/10.1007/s11077-011-9144-4

Bragg, S. 2007 “' Student voice’ and governmentality: the production of enterprising subjects?” Discourse: Studies in the Cultural Politics of Education 28(3): 343-358. doi:10.1080/01596300701458905 
Brough, M. and S. Shresthova. 2012. “Fandom meets activism: Rethinking civic and political participation.” Transformative Works and Cultures 10. Accessed May $23^{\text {rd }} 2013$. http://journal.transformativeworks.org/index.php/twc/article/view/303

City of Espoo. 2010. Operational Program for Youth Services 2010-2014. (Espoon nuorisopalvelut, toimenpideohjelma vuosille 2010-2014.) Espoon kaupunki: Nuorisopalvelut.

City of Vantaa. 2010. Operational Program for Children and Young People 2010-2012: The Participation Model. (Lasten ja nuorten Vantaa toimintaohjelma 2010-2012. Lasten ja nuorten osallisuus- ja kuulemismalli.) Vantaan kaupunki: Nuorisopalvelut.

Cornwall, A. 2008. “Unpacking ‘participation’: Models, meanings and practices.” Community Development Journal 43(3): 269-283. doi:10.1093/cdj/bsn01

Coulson, A. 2004. "Local politics, central power: the future of representative local government in England.” Local Government Studies 30(4): 467-480. doi:10.1080/0300393042000318941

Dahlgren, P. 2006. "Doing citizenship. The cultural origins of civic agency in the public sphere.” European Journal of Cultural Studies 9(3): 1367-5494. doi:10.1177/1367549406066073

Delvaux, B. and F. Schoenaers. 2012. “Knowledge, local actors and public action.” Policy and Society 31(2): 105-117. doi: 10.1016/j.polsoc.2012.04.001

Desforges, L., R. Jones, and M. Woods. 2005. “New geographies of citizenship.” Citizenship Studies 9(5): 439-451. doi:10.1080/13621020500301213

Dikeç, M. 2013. “Beginners and equals: political subjectivity in Arendt and Rancière.” Transactions of the Institute of British Geographers 38(1): 78-90. doi:10.1111/j.14755661.2012.00508.x 
Elwood, S. and K. Mitchell. 2012. “Mapping children’s politics: spatial stories, dialogic relations and political formation.” Geografiska Annaler: Series B, Human Geography 94(1): 1-15. doi:10.1111/j.1468-0467.2012.00392.x

Eur-LEX. 2001. “European Union White Paper on Youth.” Accessed May $10^{\text {th }} 2013$. http://eurlex.europa.eu/smartapi/cgi/sga_doc?smartapi!celexplus!prod!DocNumber\&lg=en\&type _doc=COMfinal\&an_doc $=2001 \&$ nu_doc $=681$

Faehnle, M., P. Bäcklund and L. Tyrväinen. 2011. “Looking for the role of nature experiences in planning and decision making: A perspective from the Helsinki Metropolitan Area.” Sustainability: Science, Practice, and Policy 7(1), 45-55.

Faludi, A. 2012. “Multi-level (territorial) governance: three criticisms.” Planning Theory \& Practice 13(2), 197-211. doi:10.1080/14649357.2012.677578

Feldmann-Wojtachnia, E., A. Gretschel, V. Helmisaari, T. Kiilakoski, A. Matthies, MeinholdS. Henschel, R. Roth, and P. Tasanko. 2010. Youth participation in Finland and in Germany. Status analysis and data based recommendations. Helsinki: The Finnish Youth Research Network. http://nbn-resolving.de/urn:nbn:de:0168-ssoar-350437 Flyvbjerg, B. (2001). Making Social Science Matter: Why Social Inquiry Fails and How It Can Succeed Again. Cambridge: Cambridge University Press.

Gerodimos, R. (2008) “Mobilising young citizens in the UK: A content analysis of youth and issue websites.” Information, Communication \& Society 11(7): 964-988. doi:10.1080/13691180802109014

Giaccaria, P. and C. Minca. 2011. “Topographies/topologies of the camp: Auschwitz as a spatial threshold.” Political Geography 30(1): 3-12. doi:10.1016/j.polgeo.2010.12.001 
Haddon, L., S. Livingstone and the EU Kids Online Network. 2012. “EU Kids Online: national perspectives.” EU Kids Online. London: The London School of Economics and Political Science. http://eprints.lse.ac.uk/46878/

Hajer, M. 2003. "Policy without polity? Policy analysis and the institutional void.” Policy Sciences, 36(2): 175-195. doi:10.1023/A:1024834510939

Häkli, J. 1998. “Discourse in the production of political space: Decolonizing the symbolism of provinces in Finland.” Political Geography 18(3): 331-363. http://dx.doi.org/10.1016/S0962-6298(97)00016-4

Häkli, J. 2008. “Regions, networks and fluidity in the Finnish nation-state.” National Identities 10(1): 5-22. doi:10.1080/14608940701819751

Häkli, J. 2009. “Boundaries of trust: building a transnational space in Haparanda-Tornio.” In Social Capital and Urban Networks of Trust, edited by Jouni Häkli and Claudio Minca. Aldershot: Ashgate, 205-232.

Häkli, J. 2013. “State space - outlining a field theoretical approach. Geopolitics 18(2): 343355. doi:10.1080/14650045.2012.723285

Häkli, J. and K.P. Kallio. 2014a. “The global as a field: Children’s rights advocacy as a transnational practice.” Environment and Planning D: Society and Space 32(2): 293309. doi:10.1068/d0613

Häkli, J. and K.P. Kallio. 2014b. “Subject, action and polis: Theorizing political agency.” Progress in Human Geography 38(2): 181-200. doi:10.1177/0309132512473869 Healey, P. 2010. Making Better Places. The Planning Project in the Twenty-First Century. Hampshire: Palgrave Macmillan.

Hillier, J. (2003) “Agon’izing over consensus: Why Habermasian ideals cannot be 'real'.” Planning Theory 2(1): 37-59. doi:10.1177/1473095203002001005 
Innes, J. and D. Booher. 2004. "Reframing public participation: Strategies for the 21st century.” Planning Theory and Practice 5(4): 419-436.

doi:10.1080/1464935042000293170

Isin, E. 2012. Citizens Without Frontiers. London: Bloomsbury Academic.

Isin, E.F. 2009. “Citizenship in flux: the figure of the activist citizen.” Subjectivity 29(1): 367-388. doi:10.1057/sub.2009.25

Jones, M. and G. MacLeod. 2004. "Regional spaces, spaces of regionalism: territory, insurgent politics and the English question.” Transactions of the Institute of British Geographers 29(4): 433-452. doi:10.1111/j.0020-2754.2004.00140.x

Kallio, K.P. 2012. “Desubjugating childhoods by listening to the child's voice and the childhoods at play.” ACME: An International E-Journal for Critical Geographies 11(1): 81-109.

Kallio, K.P. 2014a. “Intergenerational recognition as political practice.” In Intergenerational Space, edited by Robert Vanderbeck and Nancy Worth. London: Routledge, 139-154.

Kallio, K.P. 2014b. "Rethinking spatial socialization as a dynamic and relational process of political becoming.” Global Studies of Childhood 4(3): 210-223. doi:10.2304/gsch.2014.4.3.210

Kallio, K.P. 2015. “Becoming geopolitical in the everyday world.” In Children, Young People and Critical Geopolitics, edited by Peter Hopkins and Matthew Benwell. Aldershot: Ashgate. [accepted]

Kallio, K.P. and J. Häkli. 2011a. “Tracing children’s politics.” Political Geography 30(2): 99-109. doi:10.1016/j.polgeo.2011.01.006

Kallio, K.P. and J. Häkli. 2011b. “Are there politics in childhood?” Space and Polity 15(1): 21-34. doi:10.1080/13562576.2011.567897 
Kallio, K.P. and J. Häkli. 2013. “Children and young people’s politics in everyday life.” Space and Polity 17(1): 1-16. doi:10.1080/13562576.2013.780710

Kallio, K. P. and Häkli, J. (eds.) 2015. The Beginning of Politics. London: Routledge.

Kanninen, V., P. Bäcklund and R. Mäntysalo. 2013. “Trading zone and the complexity on planning.” In Urban Planning as a Trading Zone, edited by Alessandro Balducci and Raine Mäntysalo. Netherlands: Springer. doi:10.1007/978-94-007-5854-4_1

Kim, Y.M. 2012. “The Shifting Sands of Citizenship Toward a Model of the Citizenry in Life Politics.” The Annals of the American Academy of Political and Social Science 644(1): 147-158. doi:10.1177/0002716212456008

Kuusisto-Arponen, A.K. 2011. ”The politics of identity and visuality: the case of Finnish war children.” In Images in Use: Towards the Critical Analysis of Visual Communication, edited by Matteo Stocchetti and Karin Kukkonen, 181-198. Amsterdam: Benjamins.

Larkins, C. 2013. “Enacting children’s citizenship: developing understandings of how children enact themselves as citizens through actions and Acts of citizenship.” Childhood 21(1): 7-21. doi:10.1177/0907568213481815

Lazar, S. 2010. "Schooling and critical citizenship: pedagogies of political agency in El Alto, Bolivia.” Anthropology and Education Quarterly 41(2): 181-205. doi:10.1111/j.15481492.2010.01077.x

Leal, P. A. 2007. "Participation: The ascendancy of a buzzword in the neo-liberal era." Development in Practice 17(4/5): 539-548. doi:10.1080/09614520701469518

Leino, H. 2012. "Boundary interaction in emerging scenes: two participatory planning cases from Finland.” Planning Theory \& Practice 13(3): 383-396. doi:10.1080/14649357.2012.706629

Leino, H. and M. Laine. 2012. “Do matters of concern matter? Bringing issues back to participation.” Planning Theory 11(1): 89-103. doi:10.1177/1473095211417595 
Lister, R. 2007. “Inclusive citizenship: Realizing the potential.” Citizenship Studies 11(1): 49-61. doi:10.1080/13621020601099856

Lorimer, J. 2010. “International conservation ‘volunteering’ and the geographies of global environmental citizenship.” Political Geography 29(6): 311-322. doi:10.1016/j.polgeo.2010.06.004

Mäntysalo, R. and I.L. Saglie. 2010. "Private influence preceding public involvement: strategies for legitimizing preliminary partnership arrangements in urban housing planning in Norway and Finland.” Planning Theory and Practice 11(3): 317-338. doi:10.1080/14649357.2010.500123

Marston, S. A., J. P. Jones and K. Woodward. 2005. "Human geography without scale.” Transactions of the Institute of British Geographers 30(4): 416-432. doi:10.1111/j.1475-5661.2005.00180.x

Massey, D. 1992. “Politics and space/time.” New Left Review 196(Nov-Dec): 65-84.

Matthews, H. and M. Limb. 2003. “Another white elephant? Youth councils as democratic structures.” Space and Polity 7(2): 173-192. doi:10.1080/1356257032000133928

Mezzadra, S. and B. Neilson. 2012. "Between inclusion and exclusion: On the topology of global space and borders.” Theory, Culture and Society 29(4-5): 58-75. doi:10.1177/0263276412443569

Millei, Z. and R. Imre. 2009. “The problems with using the concept of ‘citizenship’ in early years policy.” Contemporary Issues in Early Childhood 10(3): 280-290. doi:10.2304/ciec.2009.10.3.280

Mitchell, K. 2003. "Educating the national citizen in neoliberal times: from the multicultural self to the strategic cosmopolitan.” Transactions of the Institute of British Geographers 28(4): 387-403. doi:10.1111/j.0020-2754.2003.00100.x 
Mitchell, K. 2006. “Neoliberal governmentality in the European Union: Education, training, and technologies of citizenship.” Environment and Planning D: Society and Space 24(2): 389-407. doi:10.1068/d1804

Mitchell, K. and W. Parker. 2008. "I pledge allegiance to... Flexible citizenship and shifting scales of belonging.” Teacher's College Record 110(4): 775-804.

Mol, A.M. and J. Law. 1994. "Regions, networks and fluids: anaemia and social topology.” Social Studies of Science 24(4): 641-671. doi:10.1177/030631279402400402

Murdoch, J. 1997. “Towards a geography of heterogeneous associations.” Progress in Human Geography 21(3): 321-337. doi:10.1191/030913297668007261

Murphy, A. 2012. “Territory’s continual allure.” Annals of the Association of American Geographers 103(5): 1212-1226. doi:10.1080/00045608.2012.696232

Noble, G. (2009) ““Countless acts of recognition’: young men, ethnicity and the messiness of identities in everyday life.” Social and Cultural Geography 10(8): 875-891. doi:10.1080/14649360903305767

Nownes, A. (2011) “Citizen participation in local government.” Encyclopedia of Public Administration and Public Policy. Taylor and Francis Online. doi:10.1081/E-EPAP2120026184

Ortner, S.B. 2006. Anthropology and Social Theory: Culture, Power, and the Acting Subject. Durham: Duke University Press.

Paasi, A. 1999. "Nationalizing everyday life: individual and collective identities as practice and discourse.” Geography Research Forum 19: 4-21.

Percy-Smith, B. 2010. “Councils, consultations and community: rethinking the spaces for children and young people's participation.” Children's Geographies 8(2): 107-122. doi:10.1080/14733281003691368 
Purcell, M. 2006. “Urban democracy and the local trap.” Urban studies 43(11): 1921-1941. doi:10.1080/00420980600897826

Saldanha, A. 2002: "Music, space, identity: Geographies of youth culture in Bangalore.” Cultural Studies 16(3): 37-350. doi:10.1080/09502380210128289

Sam, M.P. and J. Scherer. 2006. “The steering group as policy advice instrument: A case of “consultocracy” in stadium subsidy deliberations.” Policy Science 39(2): 169-181. doi:10.1007/s11077-006-9014-7

Sassen, S. 2002. "Towards post-national and denationalized citizenship." In Handbook of Citizenship Studies, edited by Engin Isin \& Bryan Turner, 277-292. London: Sage.

Secor, A.J. 2013. “Topological City”. Urban Geography 34(1): 430-444. doi:10.1080/02723638.2013.778698

Silova, I., M.A. Mead and G. Palandjian. 2014. “Pedagogies of space: (re)mapping territorities, borders, and identities in post-Soviet textbooks.” In (Re)Constructing Memory: School Textbooks, Identity, and the Pedagogies and Politics of Imagining Community, edited by James Williams. Rotterdam: SENSE Publishers, 103-130.

Silver, H., A. Scott and Y. Kazepov. 2010. "Participation in urban contention and deliberation.” International Journal of Urban and Regional Research 34(3): 453-477. doi:10.1111/j.1468-2427.2010.00963.x

Simonsen, K. 2013. "In quest of a new humanism: embodiment, experience and phenomenology as critical geography.” Progress in Human Geography 37(1): 10-26. doi:10.1177/0309132512467573

Skelcher C. and J. Torfing. 2010. “Improving democratic governance through institutional design: Civic participation and democratic ownership in Europe.” Regulation and Governance 4(1): 71-91. doi:10.1111/j.1748-5991.2010.01072.x 
Slavtcheva-Petkova, V. and S. Mihelj. 2012. “Europe - a default or a dream? European identity formation among Bulgarian and English children.” Ethnicities [EarlyView] doi:10.1177/1468796812465722

Staeheli, L. 2011 “Political geography: Where’s citizenship?” Progress in Human Geography 35(3): 393-400. doi:10.1177/0309132510370671

Staeheli, L., K. Attoh and D. Mitchell. 2013. “Contested engagements: youth and the politics of citizenship.” Space and Polity 17(1): 88-105. doi:10.1080/13562576.2013.780715

Tambakaki, P. 2011. "From citizenship to human rights: the stakes for democracy.” Citizenship Studies 13(1): 3-15. doi:10.1080/13621020802586594

Thrift, N. 2006. “Space.” Theory, Culture and Society 23(2-3): 139-155. doi:10.1177/0263276406063780

Tisdall, K., J. Davis, M. Hill and A. Prout. (eds.) 2006. Children, Young People and Inclusion: Participation for What? Bristol: The Policy Press.

Torfing, J., E. Sørensen and T. Fotel. 2009. “Democratic anchorage of infrastructural governance networks: The case of the Femern Belt Forum.” Planning Theory 8(3): 282308. doi:10.1177/1473095209104827

Tracy, K. and M. Turfy. 2007. "Speaking out in public: citizen participation in contentious school board meetings.” Discourse \& Communication, 1(2): 223-249. doi:10.1177/1750481307076008

United Nations. 1989. Convention on the Rights of the Child. Accessed February $20^{\text {th }} 2013$. http://www2.ohchr.org/english/law/crc.htm

United Nations. 2009. Committee on the Rights of the Child, General Comment No. 12, 'The right of the child to be heard'. Accessed May $10^{\text {th }} 2013$. http://www2.ohchr.org/english/bodies/crc/comments.htm 
Valentine, G. 1996. “Angels and devils: moral landscapes of childhood.” Environment and

Planning D: Society and Space 14(5): 581-599. doi:10.1068/d140581

Wood, B.E. 2012. “Crafted within liminal spaces: Young people’s everyday politics.”

Political Geography 31(6): 337-346..doi:10.1016/j.polgeo.2012.05.003

Wood, B.E. 2013. “Young people’s emotional geographies of citizenship participation:

Spatial and relational insights.” Emotion, Space and Society iFirst.

doi:10.1016/j.emospa.2013.02.004

\footnotetext{
${ }^{1}$ For a detailed account on the national system, please visit our previous publications.

2 The platforms represent different scalar dimension, namely 'The World', 'The Continent', 'The Nation', 'The Region', 'The City', and 'The School Neighborhood'. The concept of scale is used throughout the article in the political geographical sense, and not with reference to cartography.

${ }^{3}$ Income differentials in Finland are smaller than the European average. In 2010, the average income of the highest-income decile was 5.3-fold that of the lowest-income decile and Gini index 25.8 (European average 30.7), while in the countries with the highest income differentials the highest-income decile was more than tenfold. The 'middle-class childhoods' we studied can hence be outlined as 'normal childhoods'.

${ }^{4}$ For all Finnish acts and decrees mentioned in this article, translations can be found at the Finlex Data Bank (http://www.finlex.fi/en/laki/kaannokset/).

${ }^{5}$ Schooling is strongly state-promoted in Finland by free education, broad network of public institutes, and various subsidies. From kindergarten to senior high and vocational schools, most of the population is involved in pedagogical institutions.

${ }^{6}$ The comparative EU Kids Online study has made explicit that Finnish children's use and exposure to virtual media is of high level. Seventy-nine percent of Finnish children use the internet daily (European average 60\%), with an average of 95 minutes online time (European average 88 minutes) (Haddon, Livingstone and the EU Kids Online Network 2012).

${ }^{7}$ Captions coded as (city/expert). All translations by the authors.

${ }^{8}$ The expert interviews were conducted prior to the ethnographic study. The posed questions did not indicate in any way our presumptions concerning the matter, i.e. the interpretations are entirely their own.

${ }^{9}$ Most importantly Netari that brings youth workers to social media environments, and Aloitekanava that provides children and youth opportunities to introduce bill's to their local government.
} 